\title{
Development of alum from kaolin deposit using response surface methodology
}

\begin{abstract}
A novel approach of for the formation of Hydrated Sodium Aluminium Sulpahte (Alum) from metakaolin was employed in this study. This process was used to form alum from metakaolin. It majorly involves captivating the self generated energy as a result of acid solvating in metakaolin-water solution to supply the mixing and activation energies requirement of the process without external heat source. The study gives a regression equation for the formation of Alum at a given volume of acid per gram metakaolin, temperature of reaction and desired conversion level.
\end{abstract}

Keywords: kaolin, metakaolin, dealumination, alum, yield
Volume 2 Issue 3- 2018

\author{
John Busayo Adeoye, James Abiodun \\ Omoleye, Modupe Elizabeth Ojewumi \\ Department of Chemical Engineering, Covenant University, \\ Nigeria
}

Correspondence: Modupe Elizabeth Ojewumi, Chemical Engineering Department, Covenant University, PMB 1023 Sango ota, Nigeria, Tel 0802-8I59-149,

Email modupe.ojewumi@covenantuniversity.edu.ng

\section{Introduction}

Kaolinite is a clay mineral which is part of the group of industrial minerals, with the chemical composition $\mathrm{Al}_{2} \mathrm{Si}_{2} \mathrm{O}_{5}(\mathrm{OH})_{4}$. It is a layered silicate mineral, with one tetrahedral sheet linked through oxygen-atoms to one octahedral sheet of alumina octahedral. Rocks that are rich in kaolinite are known as kaolin or china clay. ${ }^{1}$ The name is derived from Kao-ling, a village near Jingdezhen, Jiangxi province, China. The name entered English in 1727 from the French version of the word: "kaolin", following Francois Xavier d'Entrecolles's reports from Jingdezhen. ${ }^{2}$ In Africa, kaolin is sometimes known as kalaba (in Gabon and Cameroon), calaba and calabachop (in Equatorial Guinea). Kaolinite has a low shrink-swell capacity and a low cation exchange capacity $(1-5 \mathrm{meq} / 100 \mathrm{~g})$. It is a soft, earthy, usually white mineral (dioctahedral phyllosilicate clay), produced by the chemical weathering of aluminiumsilicate minerals like feldspar. In many parts of the world, it is colored pink-orange-red by iron oxide, giving it a distinct rust hue. Lighter concentrations yield white, yellow or light orange colors.

The primary source for the production of alum is bauxite, but with declining deposits alternative sources are been sought. One of the handy alternatives is kaolin and that it is next to bauxite in alumina content has made it more desirable for alum production. The word alum is derived from its Latin generic form "alumen", which was applied to several astringent substances, most of which contained aluminum sulfate which are single salt alums: $\mathrm{Al}_{2}\left(\mathrm{SO}_{4}\right)_{3} \cdot \mathrm{xH}_{2} \mathrm{O}$ and double salt alums: Potassium alum, $\mathrm{K}_{2} \mathrm{SO}_{4} \cdot \mathrm{Al}_{2}\left(\mathrm{SO}_{4}\right)_{3} \cdot 24 \mathrm{H}_{2} \mathrm{O}$; Ammonium alum $\left(\mathrm{NH}_{4}\right)_{2} \mathrm{SO}_{4} \cdot \mathrm{Al}_{2}\left(\mathrm{SO}_{4}\right)_{3} \cdot 24 \mathrm{H}_{2} \mathrm{O}$; Soda alum $\mathrm{Na}_{2} \mathrm{SO}_{4} \cdot \mathrm{Al}_{2}\left(\mathrm{SO}_{4}\right)_{3} \cdot 24 \mathrm{H}_{2} \mathrm{O}$ : Ferric alum. $\mathrm{FeSO}_{4} \cdot \mathrm{Al}_{2}\left(\mathrm{SO}_{4}\right)_{3} \cdot 24 \mathrm{H}_{2} \mathrm{O}$ etc. ${ }^{3}$ Alum is used in food and pharmaceutical related industries as well as in water purification. It is also extensively used in the manufacture of vegetable glues, porcelain cements, natural deodorants, tanning, dyeing, fireproofing textiles and paper, and in alumina production for catalytic and refractory applications.

Several sintering and acid-extraction processes have been investigated for kaolin and other clays. These processes include the lime sinter process, ${ }^{4-7}$ the lime-soda sinter process, ${ }^{8}$ nitric acid process, ${ }^{9,10}$ Hydrochloric acid process ${ }^{11-14}$ and Sulfurous acid processes. ${ }^{14-16}$ The acid processes are essentially suitable for clays and kaolin low in iron and titanium oxides and they have been used in extraction of other metals. ${ }^{17}$ In these processes, calcined aluminous ore is treated with a mineral acid, such as $\mathrm{H}_{2} \mathrm{SO}_{4}$. The treatment produces soluble aluminum salt (e.g. aluminum sulfate) and the silica appears in the residue with the bulk of the impurities. Iron and titanium, also pass into solution together with aluminum salt which necessitate their removal by purification step before conversion to alumina. Early investigations of sulfuric acid processes for the production of alumina are described by Tilley GS. ${ }^{18}$ Some of the reported literature recommended calcinations temperature of 770$820^{\circ} \mathrm{C} .{ }^{19}$ Concentration of about $70 \% \mathrm{H}_{2} \mathrm{SO}_{4}$ has been patented to extract alumina from clays. Leaching with sulfuric acid was practiced at $90^{\circ} \mathrm{C}$ and $10-20 \%$ acid concentration.

Another patent reported $30 \%$ as the recommended concentration of the acid. ${ }^{12}$ reported that a temperature of $105^{\circ} \mathrm{C}$ as a recommended extraction temperature, others recommended a temperature of 70 $90^{\circ} \mathrm{C}$ for $10-2$ hours to extract $70-80 \%$ of alumina..$^{12}$ extracted alumina from Pakistani high-aluminous clays after calcinations at $700-800^{\circ} \mathrm{C}$ for one hour and leaching with sulfuric acid for $1-2$ hours at $110^{\circ} \mathrm{C}$.

Acid activation has been widely studied as chemical treatment methods for improvement of the surface and catalytic properties of fibrous clays and has been noted to induce changes in crystal structure of aluminosilicate minerals due to the dissolution of structural ions and/or rearrangement of the structure..$^{20,21}$ Literature revealed the acid activation of metakaolins. ${ }^{22-24}$

Coagulation is a process in (drinking water or industrial effluent waste) water treatments. Alum, $\mathrm{Al}_{2}\left(\mathrm{SO}_{4}\right)_{3} \cdot{ }^{14-27} \mathrm{H}_{2} \mathrm{O}$ or its equivalent double salts of either sodium or potassium is known to be the most common coagulant used in water treatment due to its effectiveness in treating a wide range of water types. ${ }^{25}$ Alum's relatively low cost makes it to be the preferred coagulant despite its few short comings in terms of large sludge production and limited $\mathrm{pH}$ range of effectiveness when compared to the more recent coagulants such as polyaluminium chloride $(\mathrm{PACl})$, polyaluminiumsulphate. ${ }^{24-28}$

Design of experiments (DOE) can be defined as the systematic method of determining the relationship between factors affecting a 
process and the output of that process. DOE is an advanced statistical tool to study efficiently the effect of a large number of variables with a minimum effort in data collection. ${ }^{29,30}$ This investigates the effects of input variables (factors) on output variable (response) simultaneously. It is majorly used to find the cause-and-effect relationships, which is needed to manage process inputs in order to optimize the experimental outputs. In an experiment, one or more process factors or variables are deliberately changed in order to observe the effect the changes have on one or more response variables. The (statistical) design of experiments (DOE) is an efficient procedure for planning experiments so that the data obtained can be analyzed to yield valid and objective conclusions. An experimental design is the laying out of a detailed experimental plan in advance of doing the experiment. Simple experimental design and statistical tools for data analysis can provide much information about the system under investigation after only a few experiments. Such information can be key in decision making for further experiments and can enable the development of robust and reliable protocols for chemical synthesis, analytical methods or biological assays. ${ }^{31}$

\section{Experimental procedures}

\section{Beneficiation}

The raw kaolin clay used was procured from a kaolin field in Ogun State, Nigeria. The raw kaolin sample was crushed and grinded using mortar and pestle. The grinded Kaolin was wet-beneficiated with deionized water in order to purify it from physically and chemically combined impurities such as metallic oxide, soluble salts and grits. The wet kaolin was stirred continuously using electric stirrer at 200rpm for 30 minutes in order to separate all the agglomerates of clay particles. It was then sieved through a $106 \mathrm{micron}$ to get rid of intermediate coarse associated mineral particles. This process was done twice in order to remove all traces of grits. The fine kaolin suspension was thereafter allowed to settle overnight by gravity, decanted and further dewatered using filter paper, dried atmospherically for 2 days and further dried at $60^{\circ} \mathrm{C}$ in an electric oven for $4 \mathrm{hrs}$. The dried beneficiated kaolin lumps were milled to very fine particle size and the sample subsequently was analyzed. Table1 shows its major oxide constituents.

Table I Chemical composition of raw kaolin beneficiated kaolin and metakaolin

\begin{tabular}{llll}
\hline $\begin{array}{l}\text { Chemical } \\
\text { constituent }\end{array}$ & $\begin{array}{l}\text { Arobieye } \\
\text { kaolin }\end{array}$ & $\begin{array}{l}\text { Beneficiated } \\
\text { kaolin }\end{array}$ & Metakaolin \\
\hline Oxides & Mol \% & Mol \% & Mol \% \\
\hline $\mathrm{SiO}_{2}$ & 48.79 & 45.94 & 49.24 \\
$\mathrm{Al}_{2} \mathrm{O}_{3}$ & 33.58 & 34.84 & 36.6 \\
$\mathrm{Fe}_{2} \mathrm{O}_{3}$ & 2.65 & 2.88 & 3.03 \\
$\mathrm{CaO}$ & 2.98 & 3.10 & 3.11 \\
$\mathrm{MgO}$ & 0.58 & 0.59 & 0.63 \\
$\mathrm{SO}_{3}$ & 0.04 & 0.04 & 0.02 \\
$\mathrm{Na}_{2} \mathrm{O}$ & 0.07 & 0.07 & 0.07 \\
$\mathrm{~K}_{2} \mathrm{O}$ & 0.01 & 0.01 & 0.01 \\
$\mathrm{TiO}_{2}$ & 1.48 & 1.64 & 1.62 \\
$\mathrm{P}_{2} \mathrm{O}_{5}$ & 0.10 & 0.10 & 0.01 \\
$\mathrm{Mn}_{2} \mathrm{O}_{3}$ & 0.01 & 0.01 & 0.02 \\
\hline $\begin{array}{l}\mathrm{Si}^{\prime} \mathrm{Al} \\
\text { molar ratio } \\
(\mathrm{Mol})\end{array}$ & 2.47 & 2.24 & 2.29 \\
\hline
\end{tabular}

\section{Calcination}

The dry beneficiated kaolin was calcined at $850^{\circ} \mathrm{C}$ in an electric furnace (Nabertherm, $301400^{\circ} \mathrm{C}$ ) for 6hours. ${ }^{32-34}$ The dried beneficiated kaolin was heated in a programmable furnace from room temperature to the desire temperature of $850^{\circ} \mathrm{C}$ at heating rate of $10^{\circ} \mathrm{C} / \mathrm{min}$. The metakaolin obtained was cooled in a desiccators and then package for analysis.

\section{Dealumination of metakaolin}

In a batch reaction, $46 \mathrm{~g}$ of metakaolin was added to $156 \mathrm{ml}$ of deionized water in a three-neck round bottom flask placed on a magnetic stirrer. On the two necks were fitted with a reflux condenser and a thermometer while the neck was closed with a rubber cork. $98 \mathrm{wt} \% \mathrm{H}_{2} \mathrm{SO}_{4}$ was added to the metakaolin slowly in the flask. ${ }^{33-35}$ The volume of acid added was varied with constant residence time of 10 minutes. The reaction was quenched with $200 \mathrm{ml}$ of deionized water, transferred to $500 \mathrm{ml}$ beaker and allowed to cool and settled down. The beaker content was filtered with filter paper (whatman 1-541). Dealuminated kaolin was dried atmospherically for 2 days and further dried at $60^{\circ} \mathrm{C}$ in an electric oven for $4 \mathrm{hrs}$. The dried sample lumps were milled to very fine particle size with ball and the sample subsequently was analyzed.

\section{Optimization consideration of the process scale-up}

In this research work, set of runs, $20 \mathrm{ml}, 25 \mathrm{ml}, 30 \mathrm{ml}, 35 \mathrm{ml}$ and $40 \mathrm{ml}$ of $98 \mathrm{wt} \% \mathrm{H}_{2} \mathrm{SO}_{4}$ per batch were added to $46 \mathrm{~g}$ of metakaolin in order to form Alum. The modification scheme was done in order to assess the extent to which the operation will affect alum yield and conversion (Figure 1)

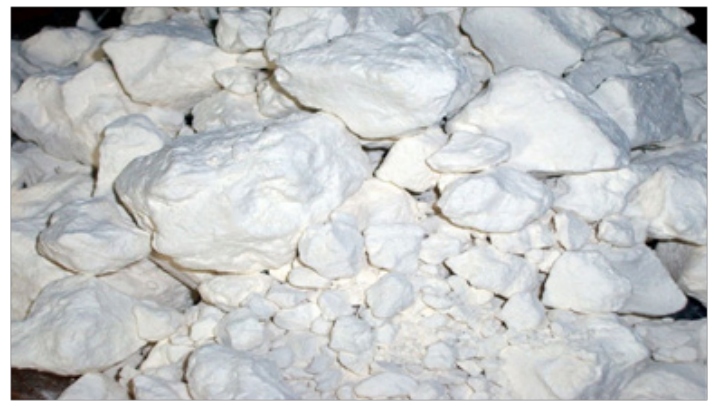

Figure I Picture of raw Kaolin.

\section{Results and discussion}

\section{Material balance}

Table1 shows the major oxide constituents of raw Kaolin, Beneficiated Kaolin and metakaolin. The reduction in the $\mathrm{Si} / \mathrm{Al} \mathrm{Mol} \%$ from 2.47 (in the raw clay) to 2.29 (in the metakaolin) respectively, implies that the screened out particles are silica rich minerals. High $\mathrm{Fe}_{2} \mathrm{O}_{3}$ and $\mathrm{CaO}$ composition in the samples may be attributed to sources, location and mode of formation i.e. either potash or ferric kaolin. On the average, about $64 \mathrm{wt} \%$ pure kaolin recovery was attained, the amount of Alumina in metakaolin is $36.6 \mathrm{wt} \%$. The potential yield of Alum from kaolin is enhanced through the formation of metakaolin from $33.58 \mathrm{wt} \%$ to $36.6 \mathrm{wt} \%$.

\section{Optimization consideration and process scale-up}

The effect of volume of acid/g metakaolin conversion and temperature of reaction are shown in Figures 2-4. The percentage alum yield increases as the volume of acid per batch increases. This 
implies that Alum conversion increase as the volume of acid per gm metakaolin increase. Figure 2 shows the surface plot of the dependency of conversion and the volume of acid used on the mass of alum, while Figure 3 shows the surface plot of the dependency of temperature and volume of acid and Figure 4 shows the dependency of temperature and conversion on mass of alum produced respectively.

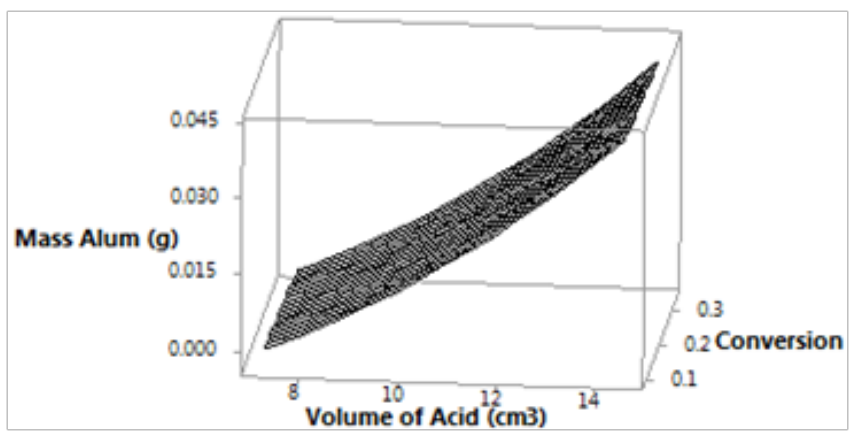

Figure 2 Surface plots of Mass Alum vs Conversion vs Volume of Acid.

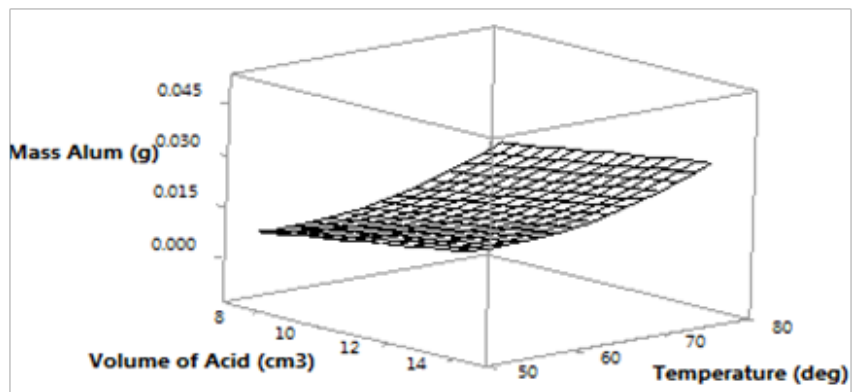

Figure 3 surface plots of Mass Alum vs Temperature vs Volume of Acid.

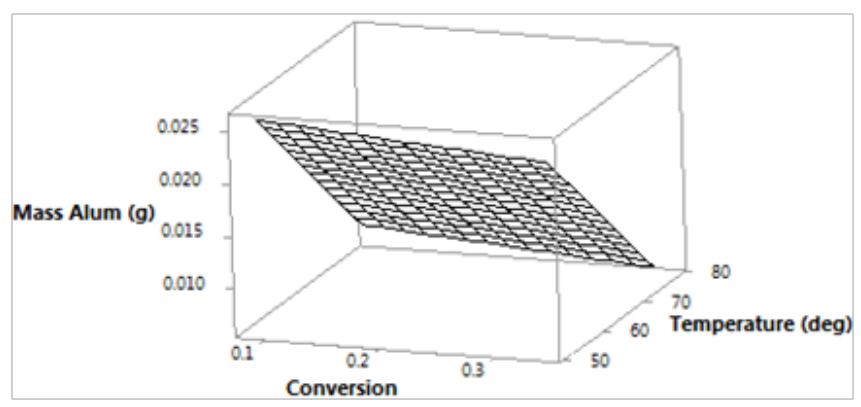

Figure 4 Surface plot of Mass Alum vs Temperature vs Conversion.

Regression Equation in Uncoded Units

Mass Alum $=0.03505-0.001016$ Vol Acid-0.007983 Conv.0.000680 Tempt. $+0.000319 \mathrm{Vol}$ Acid*Vol Acid

The above regression equation helps to predict the quantity of Alum that can be produced per gram metakaolin at a given volume Acid/g metakaolin decreased conversion and at a given temperature. Second order differentiation of mass Alum per metakaolin with respect to volume of acid of metakaolin is positive. This indicates that there is a minimum volume of acid per $g$ metakaolin that cannot be exceeded for the formation of Alum using this novel energy saving method.

\section{Conclusion}

It can be concluded from this work that Alum can be produced from metakaolin without any heat of reaction supply. The quantity of Alum produced per gram metakaolin can be predicted as a function of the volume of acid used, conversion level designed and temperature of reaction. The regression equation generated can be used to predict the amount of alum that can be produced with known volume of acid and controlled temperature.

\section{Acknowledgements}

None.

\section{Conflict of interest}

Author declares that there is no conflict of interest.

\section{References}

1. Pohl WL. Economic geology: principles and practice: metals, minerals, coal and hydrocarbons-introduction to formation and sustainable exploitation of mineral deposits. Chichester: Wiley-Blackwell; 2011. p. 331 .

2. Harper D. Kaolin, Online Etymology Dictionary. 2012.

3. Othmer K. Encyclopedia of Chemical Technology. Wiley Interscience. 1997(2):219-268.

4. McCormick PG, Picaro T, Smith PAI. Mechanochemical Treatment of High silica Bauxite with Lime. Minerals Engineering. 2002;15(4):211-214.

5. Wu Y, Ping Xu, Jiao C, et al. Effect of Temperature on Phase and Alumina Extraction Efficiency of the Product from Sintering Coal Fly Ash with Ammonium Sulfate. Chinese Journal of Chemical Engineering. 2014;22(11-12):1363-1367.

6. Abdul K, Shabir Q, Iqbal A, et al. Extraction of Alumina from highAluminous Clays. Pakistan Journal of Science Research. 1956;8:88-93.

7. Salahudeen N, Abdulkarim SA, Ala'a H Al, et al. Synthesis, characterization and adsorption study of nanosized activated alumina synthesized from kaolin using novel method. Powder Technology. 2015;280:266-272.

8. Park KU, Jeong J. Manufacture of Low-Soda Alumina from Clay. Industrial \& Engineering Chemistry Research. 1996;35(11):4379-4385.

9. Bakr MY, El-Abd MA. Acid Process for the Recovery of Alumina, Nitric Acid Process. Sprechsaal Jahrg. 1969;102(13):535-537.

10. Johnson PW, Peters FA. Methods for Producing Alumina from Clay, an Evaluation of a Nitric Acid Process: US Bureau of Mines R I. No. 6431.1964 .

11. Ojewumi ME, Adeyemi AO, Ojewumi EO. Oil Extract from Local Leaves-An Alternative to Synthetic Mosquito Repellants. Pharmacophore. 2018;9(2):1-6.

12. Reddy BR, Mishra SK, Banerjee GN. Kinetics of Leaching of a Gibbsitic Bauxite with Hydrochloric Acid. Hydrometallurgy. 1999;51(1):131-138.

13. Zivan DZ, Nada DT. Kinetics and Mechanism of Leaching of Low Quality Boehmite with Hydrochloric Acid. Hydrometallurgy. 1994;36(2):247-258.

14. Eisele JA, Bauer DJ, Shanks DE. Bench-Scale Studies to Recover Alumia from Clay by a Hydrochloric Acid Process. Industrial \& Engineering Chemistry Product Research and Development. 1983;22(1):105-110. 
15. Ojewumi ME, Omoleye JA, Ajayi AA. The Effect of Different Starter Cultures on the Protein Content in Fermented African Locust Bean (Parkia Biglobosa) Seeds. International Journal of Engineering Research \& Technology. 2016;5(4):249-255.

16. Stanislaw B. Obtaining Pure Aluminum Compounds from Clays and Kaolin. Technology University, Warsaw Zeszyty Nauk, Pilotech, Warsaw. 1954;9(1):11-59.

17. Wang X, Yang D, Srinivasakannan C, et al. A Comparison of the Conventional and Ultrasound-Augmented Leaching of Zinc Residue Using Sulphuric Acid. Arabian Journal for Science and Engineering. 2014;39(1):163-173.

18. Tilley GS, Millar RW, Ralston OC. Acid Process for the Extraction of Alumina, US Bureau of Mines Bull. No. 267.1927.

19. Ajemba RO, Onukwuli OD. Process Optimization of Sulphuric Acid Leaching of Alumina from Nteje Clay Using Central Composite Rotatable Design. International Journal of Multidisciplinary Sciences and Engineering. 2012;3(5):233-239.

20. Belver C, Munoz MAB, Vicente MA. Chemical Activation of a Kaolinite under Acid and Alkaline Conditions. Chem Mater. 2002;14(5):20332043.

21. Coma A, Misfud A, Sanz E. Kinetics of the Acid Leaching of Palygorskite: Influence of the Octahedral Sheet Composition. Clay miner. 1990;25:197-205.

22. Caballero I, Colina FG, Costa J. Synthesis of X-type zeolite from dealuminated kaolin by reaction with sulfuric acid at high temperature. Ind Eng Chem Res. 2017;46(4):1029-1038.

23. Colina FG, Esplugas S, Costa J. High-temperature Reaction of Kaolin with Sulfuric Acid. Ind Eng Chem Res. 2002;41(17):4168-4173.

24. Hulbert SF, Huff DE. Kinetics of alumina removal from calcined kaolin with nitric, sulphuric and hydrochloric acids. Clay Minerals. 1970;8(337):340-345.

25. McCurdy K, Carlson K, Gregory D. Floc morphology and cyclic shearing recovery: comparison of alum and polyaluminum chloride coagulants. Water Res. 2004;38(2):486-494.
26. Xu GR, Yan ZC, Wang YC et al. Recycle of Alum recovered from water treatment sludge in chemically enhanced primary treatment. Journal of Hazardous Materials. 2009;161(2-3):663-669.

27. Wu X, Ge X, Wang D, et al. Distinct mechanisms of particle aggregation induced by alum and PACl: Floc structure and DLVO evaluation. Colloids and Surfaces A: Physicochemical and Engineering Aspect. 2009;347(1-3):56-63.

28. Ojewumi ME, Emetere ME, Babatunde ME. et al. In Situ Bioremediation of Crude Petroleum Oil Polluted Soil Using Mathematical Experimentation. International Journal of Chemical Engineering. 2017;5184760:1-11.

29. Ojewumi ME, Omoleye JA, Ajayi AA. Optimization of Fermentation Conditions for the Production of Protein Composition in Parkia biglobosa Seeds using Response Surface Methodology. International Journal of Applied Engineering Research. 2017;12(22):12852-12859.

30. Ojewumi ME, Adesanmi AA, Oyinlola MO, et al. Pozzolanic properties of Waste Agricultural Biomass-African Locust Bean Pod Waste. World Journal of Environmental Biosciences. 2017;6(3):1-7.

31. Ojewumi ME. Optimizing the conditions and processes for the production of nutrient from Parkia biglobosa. Ph.D. dissertation, Chemical Engineering Department. Nigeria: Covenant University; 2016.

32. Babalola R, Omoleye JA, Ajayi O, et al. Comparative Analysis of Zeolite $\mathrm{Y}$ from Nigerian Clay and Standard Grade, $2^{\text {nd }}$ International Conference on African Development Issues (CU-ICADI). Materials Technology Track. 2015;179-182.

33. Adeoye JB, Omoleye JA, Ojewumi ME, et al. Synthesis of Zeolite $\mathrm{Y}$ from Kaolin using Novel method of Dealumination. International Journal of Applied Engineering and Research. 2017;12(5):755-760.

34. Adeoye JB, Omoleye JA. Development of Zeolite Y from Arobieye Mined Kaolin, $3^{\text {rd }}$ International Conference on African Development Issue (CU-ICADI). 2016;582-583.

35. Ojewumi ME, Owolabi RU. The Effectiveness of the Extract of 'Hyptis Sauveolens' Leave (A Specie of Effinrin) in Repelling Mosquito. Transnational Journal of Science and Technology. 2012;2(8):79-87. 